\title{
Nucleation efficacy and flexural strength of Novel Leucite Glass-Ceramics
}

\author{
Michael J. Cattell ${ }^{\star a}$, Christian Patzig ${ }^{\mathrm{b}}$, Sami Bissasu ${ }^{\mathrm{a}}$, Andreas Tsoutsos ${ }^{\mathrm{a}}$, \\ Natalia Karpukhina ${ }^{a}$
}

a Centre for Oral Bioengineering, Bart's and the London, School of Medicine and Dentistry, Queen Mary University of London, Turner Street, Whitechapel, E1 2AD, UK.

b Fraunhofer Institute for Microstructure of Materials and Systems IMWS, WalterHuelse-Strasse 1, 06120 Halle (Saale), Germany

*corresponding author; email address: m.cattell@qmul.ac.uk 


\section{Abstract}

Objectives: To optimise the nucleation mechanism in leucite glass-ceramics to allow more efficacious glass-ceramic manufacture and improvements in microstructure and mechanical reliability.

Materials and Methods: An alumino-silicate glass was designed and synthesised using melt quench methods. The glass was crushed and milled using various milling times (48-93h) and spray drying. Nucleation and growth heat treatment schedules were applied to synthesize glass-ceramics. Glass/ glass-ceramic powders and frit specimens were characterised using differential scanning calorimetry (DSC), transmission electron microscopy (TEM), energy-dispersive X-ray spectrometry (EDX), magic angle spinning nuclear magnetic resonance Spectroscopy (MAS-NMR) and X-Ray diffraction analyses (XRD). Glass-ceramic specimens were tested using the biaxial flexural strength test (BFS).

Results: Application of defined nucleation heat treatments resulted in the synthesis of $\mathrm{Na} / \mathrm{Ca}$ titanates. NMR indicated changes to the ${ }^{23} \mathrm{Na}$ glass spectra in the nucleated glass and TEM/EDX the presence of $\mathrm{Na} / \mathrm{Ca} / \mathrm{Ti}$ domains $(<200 \mathrm{~nm})$ within the leucite crystals and associated with the nucleation of the leucite phase. XRD confirmed the presence of a bulk leucite phase in the glass-ceramics. SEM/TEM confirmed the crystallisation of the leucite phase (65.5-69.3\%) in a thermally matched glass, in conjunction with the nano $\mathrm{Na} / \mathrm{Ca}$ titanate phase. The leucite glass-ceramics resulted in a high BFS (255-268 MPa), with reduction in powder milling time prior to heat treatments having no significant effect on flexural strength and reliability $(p>0.05)$. 
Significance: $\mathrm{Na} / \mathrm{Ca}$ titanates were synthesised in leucite glass-ceramics for the first time and associated with its nucleation and efficacious growth. This nucleation optimisation provides opportunities for more efficient manufacturing and microstructural/ mechanical reliability improvements. Improved synthesis of high strength/reliable leucite glass-ceramics is useful for construction of aesthetic minimally invasive restorations.

Key Words: Glass-ceramic, X-ray Diffraction, Transmission electron microscopy, Tetragonal Leucite, Flexural strength, Crystallisation, NMR. 


\section{Introduction}

Glass-ceramics are widely used in biomedical and industrial applications and their efficient, low-cost synthesis are important parameters to consider when scaling new materials for dental applications. The production of mainstream glass-ceramics is via a high temperature melt/quench synthesis of glasses and their subsequent heat treatments, to control the crystal phase and the residual glass. Careful control of these processes is important as they can influence the chemical, thermal, mechanical, biological and optical properties of the final glass-ceramic [1], which has implications for their clinical performance and the patient acceptance of these materials. In particular, leucite glass-ceramics are used in dentistry for the construction of allceramic restorations including crowns, inlays and veneers and for fusing to metal substrates to produce porcelain fused to metal bridges, implants and crowns [2].

Glass-ceramics are synthesised by the controlled nucleation and crystallisation of the produced glass [3], so that a high-volume fraction of fine crystals can be produced which are thermally compatible with residual glass phase. They are produced via a surface or bulk crystallisation process, with the former being the most prevalent [4]. The literature indicates leucite glass-ceramics can be crystallised via a surface crystallisation mechanism [5]. There is however also experimental evidence to suggest that these processes can happen sequentially according to specific glass powder sizes in leucite glass-ceramics [6].

The current authors previously utilised surface crystallisation mechanisms to reduce crystal size and increase crystal area fraction (24.9-29.3\%), creating fine $\left(<1 \mu \mathrm{m}^{2}\right)$ and 
nano-sized $\left(<0.1 \mu \mathrm{m}^{2}\right)$ leucite glass-ceramics $[7,8]$ with high flexural strengths (253.8255.0 MPa) and producing low enamel wear [9]. These formulations however contained very low quantities of titanium dioxide $(0.3 \mathrm{~mol} \%)$, which is a copious nucleating agent used successfully in many glass systems to effect bulk crystallisation. This is due to its ability to induce phase separation by its displacement from the glass network, in combination with a divalent cation, and effecting a change in its coordination state. The resultant structural changes to the local glass network and medium range reorganisation encourages nucleation [10]. A number of precursor titanate phases have also been associated with the efficacious crystal growth of other glass-ceramic systems $[11,12]$.

The aim of the study is therefore to synthesise a novel aluminosilicate glass designed using Appen factors with increased $\mathrm{TiO}_{2}$ content [13], to induce any potential titanate phase formation found in other glass-ceramic systems in order to optimise the nucleation process. Optimisation of the nucleation mechanism in surface crystallised leucite glass-ceramics may allow more efficacious glass-ceramic manufacture and improvements in the microstructure and mechanical reliability. 


\section{Materials and Methods}

\subsection{Glass Synthesis}

An alumino-silicate glass was commercially synthesized (Cera Dynamics Ltd, Stokeon-Trent, UK) by heating reagents in a high temperature custom made furnace (James Kent, UK) at $10^{\circ} \mathrm{C} / \mathrm{min}$ to $1550^{\circ} \mathrm{C}$ (5 h hold). The glass was of the following X-ray fluorescence (based on BSEN ISO 12677:2011) composition (mol \%); $\mathrm{SiO}_{2}(69.4 \%)$, $\mathrm{Al}_{2} \mathrm{O}_{3}(10.5 \%), \mathrm{K}_{2} \mathrm{O}(12.0 \%), \mathrm{CaO}(1.8 \%), \mathrm{TiO}_{2}(1.3 \%), \mathrm{Na}_{2} \mathrm{O}(2.4 \%), \mathrm{Li}_{2} \mathrm{O}(1.9$ $\%), \mathrm{B}_{2} \mathrm{O}_{3}(0.7 \%)$. The glass frit was quenched in water and ball milled using a twostage industrial process, with second stage intervals up to $93 \mathrm{~h}$, followed by spray drying (Niro Atomizer, Denmark) of one of the powders. Glass frit specimens were also retained for later analysis. Ball milled (48h, $71 \mathrm{~h}$ and $93 \mathrm{~h})$ and ball milled and spray dried powders (93h) were used to produce glass-ceramics for flexural strength testing.

\subsection{DSC Nucleation experiment}

The spray dried glass powder (93h) was characterized using a DSC (Stanton Redcroft DSC 1500, Rheometric Scientific, Epsom, UK), with matched pairs of platinumrhodium crucibles and alumina used as the reference material. To establish the optimum nucleation temperature, powder samples (50 mg per sample) were run from $25^{\circ} \mathrm{C}$ to $582^{\circ}, 592^{\circ} \mathrm{C}, 602^{\circ} \mathrm{C}, 612^{\circ} \mathrm{C}, 622^{\circ} \mathrm{C}$ or $632^{\circ} \mathrm{C}$ with a $1 \mathrm{~h}$ hold, and then ramped to $1100^{\circ} \mathrm{C}$ (no hold), at a heating rate of $20^{\circ} \mathrm{C} / \mathrm{min}$. 


\subsection{Glass-ceramic synthesis}

Refractory trays were produced using investment powder and liquid (IPS press Vest speed, Lot no: Powder TL3033 and Liquid TL3022, Ivoclar-Vivadent, Schaan, Liechtenstein) vacuum mixed, set and pre-heated $\left(850^{\circ} \mathrm{C}\right)$ according to the manufacturers' instructions. The ball milled glass powders (Grp 1; 48h, Grp 2; 71h and Grp 3; 93h) and Grp 4; ball milled and spray dried, 93h) were placed into the refractory trays and heated in a furnace (Lenton 1600 , Hope Valley, UK) at $10^{\circ} \mathrm{C} / \mathrm{min}$ to $592{ }^{\circ} \mathrm{C}(1 \mathrm{~h}$ hold $)$, then ramped at $10^{\circ} \mathrm{C} / \mathrm{min}$ to $1040^{\circ} \mathrm{C}$ (30 min hold) and air quenched. This heat treatment was used for all mechanical testing and SEI analysis specimens in this paper. The heat-treated glass-ceramic powders were next ballmilled for $1 \mathrm{~h}$ and screened through a $125 \mu \mathrm{m}$ sieve (Endescott Ltd, London, UK).

The $93 \mathrm{~h}$ spray dried glass was also heated from $25^{\circ} \mathrm{C}$ to $602^{\circ} \mathrm{C}(1 \mathrm{~h} \mathrm{hold})$, at $20^{\circ} \mathrm{C} / \mathrm{min}$, then ramped up to $1040^{\circ} \mathrm{C}$ (30 min hold) before air quenching for TEM analysis only.

\subsection{Test specimen fabrication}

The group 1-4 glass-ceramic powders (1.1g) were mixed with $0.4 \mathrm{mls}$ modelling liquid (Build-up, IPS Classic N, Ivoclar-Vivadent, Lot no: P75211) and used to fabricate disc specimens ( $2 \mathrm{~mm}$ thickness $\times 14 \mathrm{~mm}$ diameter) using a cylindrical steel mold with plunger (16 $\mathrm{mm}$ in diameter) under a hydraulic press at 1 bar pressure for $1 \mathrm{~min}$. The compacts were sintered under partial vacuum in a porcelain furnace (Multimatt MCII, Dentsply, Konstanz, Germany) from $538 \mathrm{C}$ to $1040{ }^{\circ} \mathrm{C}$ (38 C/min ramp) with a 2 min hold. Disc specimens were next wet ground with P1000 grade silicon carbide paper. 


\subsection{Biaxial Flexural Strength Testing}

The ball-on-ring test was used to test the biaxial flexural strength (BFS) of the glassceramic disc specimens (groups 1-4) prepared as explained in section 2.4. Disc specimens ( $n=30$ per group, $2 \mathrm{~mm}$ depth $\times 14 \mathrm{~mm}$ diameter) were placed on a $10 \mathrm{~mm}$ diameter knife-edge ring support and centrally loaded with a $4 \mathrm{~mm}$ diameter spherical ball indenter at a crosshead speed of $1 \mathrm{~mm} / \mathrm{min}$ until specimen failure. The BFS was calculated using the Timoshenko and Woinowsky-Krieger equation [14]:

$\sigma_{\max }=\mathrm{P} / \mathrm{h}^{2}\{(1+\mathrm{v})[0.485 \mathrm{x} \ln (\mathrm{a} / \mathrm{h})+0.52]+0.48\}$

Where $\sigma$ max is the maximum tensile stress; $P$ is the load at fracture; $h$ the specimen thickness; $\mathrm{a}$ is the radius of knife-edge ring support and $\mathrm{v}$ is Poisson's ratio (taken as 0.25) [15]. Test groups were compared using a One-way ANOVA (Sigma Stat, version 2.03, SPSS Inc., Chicago, USA) and the Holm-Sidak method ( $p<0.05)$. Weibull analysis (Supersmith software version 5, Fulton Findings, USA) was used to calculate the Weibull modulus and characteristic strength. The equation of the Weibull twoparameter distribution function used was:

$P_{f}=1-\exp \left[-\left(\frac{\sigma}{\sigma_{0}}\right)^{m}\right]$

Where $P_{f}$ is the probability of failure; $\sigma \sigma$ is the strength at a given $P_{f}$ value; $\sigma_{0}$ is the characteristic strength and $m$ is the Weibull modulus. Test groups were compared according to the overlap of their double-sided confidence intervals at the $95 \%$ level. 


\subsection{Transmission electron microscopy}

Transmission electron microscopy (TEM) analysis of the glass and glass-ceramic samples was performed using a $\operatorname{Titan}^{3}$ 80-300 electron microscope (Thermo Fisher Scientific - FEI company, Hillsboro, Oregon, USA), with an acceleration voltage of 300 kV. Glass frit samples were analysed before and after the $592^{\circ} \mathrm{C}$ (1h hold), and $602^{\circ} \mathrm{C}$ (1h hold) nucleation heat treatments. The glass-ceramic specimens produced in section 2.3 (93h milled, spray dried) were also analysed. Scanning TEM (STEM) was also carried out to image the samples, making use of a high-angle annular dark field (HAADF) detector (Model 3000, Fischione, Export, Pensylvania, USA).

Energy dispersive X-Ray analyses (EDXS) were performed using a Super-X EDX detector that was equipped with four SDD detectors (FEI), to collect lateral distribution mappings of chosen elements. These element distribution mappings were derived by evaluating the lateral distribution of the peak intensity, i.e. the area underlying the $K_{\alpha}$ edges of the analysed elements, with an automatic routine provided by the software (Esprit, Bruker, Germany). EDX-based quantitation (Cliff-Lorimer approach, spectrum peak deconvolution with Bayes algorithm) of the composition of chosen sub-areas of some of these element distribution mappings was also done. The elements $\mathrm{Li}$ and B were not considered for distribution mapping and quantitation due to their low EDX detection limit. The (S)TEM sample preparation was carried out using a mechanical wedge-polishing routine (Multiprep ${ }^{\mathrm{TM}}$ polishing system, Allied high Tech products Inc, Rancho Dominguez, CA., USA) followed by a low-energy (2.5 keV) $\mathrm{Ar}^{+}$broad beam final milling step (precision ion polishing system (PIPS), Gatan Inc., Pleasanton, CA.,USA), to achieve electron transparency as well as to remove any residue from the mechanical polishing. 


\subsection{Secondary Electron Imaging (SEI)}

Glass-ceramic specimens were polished to $1 \mu \mathrm{m}$ alumina micropolish (Lot no: 03350275, Buehler, Coventry, UK) and etched using 0.1\% hydrofluoric acid for $60 \mathrm{~s}$. Specimens were gold coated using a sputter coater (Agar Scientific Ltd., UK) for $30 \mathrm{~s}$ at $40 \mathrm{~mA}$ and imaged using a field emission scanning electron microscope (FEI Inspect F, Hillsboro, Oregon, USA), using secondary electron imaging. Quantitative image analysis (Sigma Scan Pro 5.0, Systat Software, Inc., Chicago, IL, USA) was used on the SEM photomicrographs to ascertain $(\times 3500$ magnification, area $=2255$ $\mu \mathrm{m}^{2}$ ) the particle size and area fraction.

\section{$2.9 \quad$ X-ray Diffraction Analysis}

The glass powders before and after crystallisation heat treatments were analysed using a Panalytical X'Pert Pro powder diffractometer (Panalytical B.V., Almelo, The Netherlands). CuKa radiation was used with the tube powered at $45 \mathrm{kV}$ and $40 \mathrm{~mA}$. Data was collected continuously with an X'Celerator solid state multistrip detector from $5^{\circ}$ to $70^{\circ}$ ( $2 \Theta$ range) with a step size of $0.0334^{\circ}$ and a step time of $200.03 \mathrm{~s}$. Calibration was carried out using NIST standard reference material 660 a (lanthanum hexaboride). To identify the crystalline phases, diffraction patterns were compared with tetragonal leucite (ICDD: 00-038-1423), using the ICDD PDF2 database (Newtown Square, PA, USA) and X'Pert Plus software (version 1.0, Philips Analytical, The Netherlands). 


\subsection{Solid state MAS-NMR}

The glass powders before and after heat treatment were analysed using solid state ${ }^{23} \mathrm{Na}$ and ${ }^{27} \mathrm{Al}$ MAS-NMR. The experiments were run on a Bruker Avance NEO $600 \mathrm{MHz}$ spectrometer at $14.1 \mathrm{~T}$ magnetic field. The ${ }^{23} \mathrm{Na}$ and ${ }^{27} \mathrm{Al} \mathrm{NMR}$ experiments were run at $158.7 \mathrm{MHz}$ and $156.4 \mathrm{MHz}$ resonance frequencies respectively using the double resonance Bruker probe. The samples were packed in $2.5 \mathrm{~mm}$ outer diameter zirconia rotors and spun at $20 \mathrm{kHz} .{ }^{27} \mathrm{Al}$ MAS-NMR experiments were run using a short pulse length of $0.5 \mu$ s and 0.5 s recycle delay. The spectra were referenced using a 1 mol solution of $\mathrm{Al}\left(\mathrm{NO}_{3}\right)_{3} .{ }^{23} \mathrm{Na}$ MAS-NMR experiments were run using a short pulse length $0.5 \mu$ s and 4 s recycle delay. The spectra were referenced using a 1 mol solution of $\mathrm{NaCl}$. 


\section{Results}

\subsection{Differential thermal analysis Results}

The results of the DSC nucleation experiment are shown in Figure 1, exhibiting a maximum at $\approx 602^{\circ} \mathrm{C}$. An experiment was also carried out to assess the hold time $(0.5$, 1,2 and $3 \mathrm{~h}$ ) at the nucleation temperature and $1 \mathrm{~h}$ was found to be the most efficacious.

\subsection{Biaxial flexural strength results}

The results of the BFS tests are listed in Table 1. The Mean BFS and characteristic strength values for the experimental leucite glass-ceramics (groups 1, 2, 3 and 4) were not significantly different ( $p>0.05$, Table1). There was no significant difference between Weibull modulus values for any of the experimental test groups, except between groups 3 and 4 according to the overlap of their 95\% double-sided confidence intervals (Table 1$)$.

\subsection{Transmission electron microscopy Results}

The results of TEM are illustrated in Figures $2 \mathrm{a}$-i. The frit specimen (no heat treatment) after ion beam thinning (Figs. 2a-b) indicated the glass was homogeneous on the nanoscale. Following heat treatment at $592^{\circ} \mathrm{C}$ (1h hold) the glass frit showed visual signs of phase separation (Fig. 2c). EDX revealed little differences in $\mathrm{Ti}, \mathrm{Ca}$ and $\mathrm{Na}$ but with a reduction in $\mathrm{Al}, \mathrm{Si}$ and $\mathrm{O}$ in these areas compared with the rest of the glass. In contrast, the nucleation sample $\left(602^{\circ} \mathrm{C}, 1 \mathrm{~h}\right.$ hold $)$ indicated signs of dense inclusions in the TEM bright field image (Fig. 2d). In the TEM bright field contrast mode, the appearance of such darker sample areas, like these inclusions, are due to either 
absorption (i.e., in dense sample areas, like inclusions in Fig. 2d, the primary electron beam is more strongly absorbed), and thus less intensity is detected by the camera, resulting in a dark contrast, and/or due to diffraction of the primary beam (i.e., the primary beam gets diffracted by the lattice planes of well-aligned crystalline sample areas and is, according to that diffraction, not able to pass the objective aperture and reach the camera). In the dark field TEM mode, the said objective aperture is moved in such a way that only diffracted beams can pass it and contribute to the image formation on the camera. In Fig. 2e, the same sample area as shown in Fig. $2 \mathrm{~d}$ was imaged in the dark field TEM mode. It can be seen that some of the dense inclusions, which appear dark in Fig. 2d, appear bright in Fig. 2e. This is an indication that these inclusions are crystalline. Analysis of these crystallites and associated areas (Fig. 2f), using EDX was not conclusive due to their decomposition during the analysis.

Further heat treatment of the glasses following the nucleation step $\left(592^{\circ} \mathrm{C} / 1 \mathrm{~h}\right.$ ramped to $1040{ }^{\circ} \mathrm{C}, 30 \mathrm{~min}$ hold) resulted in the crystallization of fine tetragonal leucite crystals in the glassy matrix (Fig. $2 \mathrm{~g}$ ). There was no visible microcracking in the glassy matrix (Figs $2 \mathrm{~h}-\mathrm{i} ; 3 \mathrm{a}, \mathrm{c}-\mathrm{d}$ ) and this was restricted to the crystals (Fig. 3c). Crystal twinning was in evidence in the leucite crystallites (Figs. $2 g-i, 3 a, c-d$ ). The lattice distance $d$ found in the HR-TEM images (Fig. 3b) is $d \approx 0,344 \mathrm{~nm}$ and $\mathrm{d} \approx 0,342 \mathrm{~nm}$ (Fig. 3e) is within the limitations of error, for the lattice distance of the [004] direction in tetragonal leucite $(\mathrm{d}=0,344 \mathrm{~nm})[16]$. 


\section{EDX Analysis Results}

The EDX spectra for both the crystalline and residual glass phases are shown in Figure 4 and Table 2. The elemental composition of the crystal phase closely matched the ratios for the leucite crystal phase $\left[\mathrm{K}\left(\mathrm{AlSi}_{2} \mathrm{O}_{6}\right)\right]$. The residual glass appeared to be enriched in $\mathrm{CaO}, \mathrm{TiO}_{2}$, and $\mathrm{Na}_{2} \mathrm{O}$ (Figs. 4, 5a, Table 2), compared with the starting glass composition. Domains in the leucite crystals were composed of $\mathrm{Ca}, \mathrm{Ti}$ and $\mathrm{Na}$ (Fig. 5b, c).

\subsection{Secondary Electron Imaging Results}

The results of the SEM study indicated a high area fraction (65.5-69.3\%) of tetragonal leucite crystals evenly distributed in the glassy matrix for the experimental glassceramics. The Mean (SD) leucite crystal size larea fraction of the glass-ceramic groups were; Grp 1: 0.85 (0.59) $\mu \mathrm{m}^{2} / 65.5 \%$; Grp 2: $0.74(0.48) \mu \mathrm{m}^{2} / 67.4 \%$; Grp 3: $0.62(0.42) \mu m^{2} / 69.3 \%$ and Grp 4: $0.599(0.40) \mu m^{2} / 68.4 \%$.

\subsection{X-ray Diffraction Results}

Results of the X-ray diffraction indicated an amorphous glass for the spray dried powders (93h) before and after the $602^{\circ} \mathrm{C}$ 1-h hold heat treatment (Fig 6a). The glass frit specimen $\left(602^{\circ} \mathrm{C} 1-\mathrm{h}\right)$ was similarly largely amorphous after the nucleation hold but with a small peak at $26.7^{\circ}$ 2-theta (Fig. 6b). Tetragonal leucite was identified as the bulk crystal phase following all crystallisation heat treatments (Fig. 6c). 


\subsection{Solid state MAS-NMR Results}

Figure 7a presents ${ }^{27} \mathrm{AI}$ MAS-NMR spectra of the glass-ceramic sample (a) versus the samples partially heat-treated at the temperatures around $\operatorname{Tg}\left(602^{\circ} \mathrm{C}\right.$ (b) and $592^{\circ} \mathrm{C}$ (c)) for 1 hour and the original glass powder (d). The spectrum of the glass-ceramic revealed two resolved resonance positions at 67 and $59.7 \mathrm{ppm}$. The signals are partially overlapped with the third feature can be partially seen as a shoulder at around 63ppm. This line shape of three partially overlapped sites within a one-dimensional ${ }^{27} \mathrm{AI}$ MAS-NMR spectrum is characteristic of the tetragonal leucite phase $[17,18]$. The spectra of the two partially heat-treated samples $\left(602^{\circ} \mathrm{C} / 1 \mathrm{~h}\right.$ (b) and $592^{\circ} \mathrm{C} / 1 \mathrm{~h}$ (c)) are practically identical to the spectrum of the original glass (d). All three spectra exhibit a relatively broad line at the centre of gravity at $56.5 \mathrm{ppm}$. The position of the line indicates that all aluminium species in the glass and partially heat-treated samples are four-coordinated $\mathrm{AI}(\mathrm{IV})$. The peculiar tail on the right-hand site of the ${ }^{27} \mathrm{Al}$ signal in the glass-ceramic (spectrum a) indicates the presence of the tetrahedral amorphous aluminium species $\mathrm{Al}(\mathrm{IV})$, in addition to those in the leucite crystals.

Figure $7 \mathrm{~b}$ shows ${ }^{23} \mathrm{Na}$ MAS-NMR spectra for the experimental samples (a-d). No sharp lines were seen in the spectra that can be attributed to a crystalline species. All the spectra showed relatively broad line shapes, potentially resulting from strongly overlapping contributions. The gravity centre of the signal recorded for the glass sample (d) was at -5.1ppm and the line width was the narrowest of all four spectra. The spectra of the two partially heat-treated samples $(b, c)$ are practically identical with the gravity centre at $-9.8 \mathrm{ppm}$ and the signals recorded were broader than the glass spectrum. The ${ }^{23} \mathrm{Na}$ signal of the glass-ceramic samples (a) showed the broadest line with the centre at -10.6ppm. 


\section{Discussion}

In the current work the starting glass, nucleated glass powders and frit specimen $\left(592^{\circ} \mathrm{C} 1 \mathrm{~h}\right.$ hold) were largely amorphous (Figs $\left.6 \mathrm{a}-\mathrm{b}\right)$, with signs of phase separation (Fig 2c, e). EDX was however inconclusive due to decomposition of these areas during analysis. A nucleation and growth process producing phase separated domains, random in size and low in connectivity could be responsible, including later stage coarsening $(19,20)$. The $\mathrm{TiO}_{2}(1.3 \mathrm{~mol} \%)$ content in the glass causing the generation of different Ti coordination states (4-6) [21], with the 6-coordinated species associated with alkali or alkali earth ions such as $\mathrm{Ca}^{2+}$ being displaced from the glass network. During nucleation, these changes in $\mathrm{TiO}_{2}$ coordination state can produce a more local medium range glass order and progressing to nano crystallisation [10]. The nucleation density and phase crystallisation can therefore be enhanced via titanium rich domains, concluding in fine-grained glass-ceramics [22]. Cormier et al., [23] indicated major changes in $\mathrm{Ti}$ coordination state during nucleation were changes to ${ }^{[6]} \mathrm{Ti}$ in the crystalline phases and the ${ }^{[4]} \mathrm{Ti}$ in the remaining glassy matrix, with implications that glassy matrix structural and compositional changes might influence nucleation efficacy.

Small inclusions (Fig. 2d-e) appeared present in the glass frit specimen $\left(602^{\circ} \mathrm{C}, 1 \mathrm{~h}\right.$ hold) and a small peak was visible in the XRD Plot at 26.7 2-theta (Fig. 6b), which was insufficient to identify a crystal phase. TEM dark field imaging is based on elastic scattering (diffraction) at crystal lattice planes and indicated that these areas might be crystallites (approximately $20-50 \mathrm{~nm}$ diameter, Fig. 2 e), with a density of $\approx 200$ crystals per $\mu \mathrm{m}^{3}$. These crystallites were closely associated with the earlier visual phase 
separation and with the increase in nucleation temperature $\left(10^{\circ} \mathrm{C}\right)$ at the same hold time (1h) allowing this progression.

In other glass systems $\left(\mathrm{MgO}-\mathrm{Al}_{2} \mathrm{O}_{3}-\mathrm{SiO}_{2}\right) \mathrm{TiO}_{2}$ is associated with the development of amorphous phases or titanates dependent on heat treatment conditions [24]. Titanium oxide plays a part in structural glass rearrangement due to its edge sharing linkages, forming complexes which are precursors to titanate formation, since only small atomic diffusion is necessary and structural rearrangements accommodated [10]. Phase zones in conjunction with primary crystallites (Fig. 2f) were found, but without conclusive elemental data. Fully mature crystallites following crystallisation however indicated the presence of embedded spherical domains rich in $\mathrm{Ti}, \mathrm{Ca}$ and $\mathrm{Na}$ (Figs. 5b, c). Phase separated domains containing $\mathrm{Ti}$ and $\mathrm{Ca}$ were previously associated with the crystallisation of leucite $[19,25]$. The current work clearly identifies the presence of a Ca-Na titanate phase within the crystal, which corresponds to neither a sodium titanate $\left(\mathrm{Na}_{2} \mathrm{Ti}_{3} \mathrm{O}_{7}\right.$ or $\left.\mathrm{Na}_{2} \mathrm{Ti}_{6} \mathrm{O}_{13}\right)$ or calcium titanate $\left(\mathrm{CaTiO}_{3}\right)$ but may be a solid solution. It is interesting to note that the ${ }^{23} \mathrm{Na}$ spectrum of the original glass was different from all the heat-treated samples including those partially heat treated $\left(592^{\circ} \mathrm{C} / 1 \mathrm{~h}\right.$ or $\left.602^{\circ} \mathrm{C} / 1 \mathrm{~h}\right)$ around the nucleation temperature and the final glass-ceramic sample, which were similar (Fig 7b). This indicates the sodium cations undergo transformation early during the nucleation stage. The shift to the negative values in peak position of the ${ }^{23} \mathrm{Na}$ spectra can be attributed to increase in coordination number of the cation and/or increase in $\mathrm{Na}-\mathrm{O}$ bond length [26]. Broadening of the ${ }^{23} \mathrm{Na}$ signal in the heat treated samples compared to the glass spectrum (Fig 7b) can be attributed to emerging of an additional intensity on the right hand side of the glass signal, resulting from the sodium species with different environment, compared to those 
present in the original glass. This can also lead to a negative shift in the peak position of the broad signal as observed in the ${ }^{23} \mathrm{Na}$ spectra (Fig $7 \mathrm{~b}$ ).

Calcium titanate compounds can be successfully substituted with structural changes dependant on alkali content [27, 28]. Crystal (apatite) growth was previously demonstrated on nano-crystalline sodium/calcium titanates in the form of nanobelts [29]. The current synthesised leucite crystals all appear to contain these unique NaCa titanate inclusions (Figs $2 \mathrm{~g}, \mathrm{~h}, \mathrm{i}, 3 \mathrm{a}, \mathrm{c}, \mathrm{f}$ ), where the main phase may have grown heterogeneously in close association with the new titanate phase. Several authors have demonstrated epitaxial relationships between a nucleating primary titanate phase ( $\mathrm{Zr}$ or $\mathrm{Ti}$ based) and the main crystal phase (quartz and lithium disilicate systems) and its importance [12, 30]. Zanotto [31] indicated the possibility of volume crystallisation via heterogeneous internal nucleation of impurities or secondary phases in surface nucleated systems. Fine grained leucite glass-ceramics (0.6-1.2 um) were successfully synthesized by the addition of nano-sized leucite seeds, with no transition product and bypassing nucleation via a template driven process [32]. The current synthesized $\mathrm{Na}$-Ca titanate seeds appear to produce an interface for leucite growth (Fig. 2f) and it is likely that the local glass composition close to this phase has a different chemistry. Since $\mathrm{Ca}, \mathrm{Ti}$ and $\mathrm{Na}$ are incorporated into these crystallites, it can be assumed that the glass volume that directly surrounded these areas initially had a larger concentration in $\mathrm{K}_{2} \mathrm{O}$ and $\mathrm{Al}_{2} \mathrm{O}_{3}$ than the original glass, providing favorable conditions for the crystallization of leucite. The ${ }^{27}$ Al MAS-NMR spectra (Fig. 7a) revealed that the aluminium environment in the glass did not change on nucleation heat treatment regardless of the temperature, with the four-coordinated $\mathrm{AI}(\mathrm{IV})$ species 
present. This would allow ease of structural reorganisation for crystallisation, due to reduction of the kinetic barrier for nucleation and the surface energy [33].

Following crystallization, EDX of the crystal phase indicated elemental compositional ratios related (Figs. 4, Table 2) to the leucite crystal phase $\mathrm{K}\left(\mathrm{AlSi}_{2} \mathrm{O}_{6}\right)$. The onedimensional ${ }^{27} \mathrm{Al}$ MAS-NMR spectrum (Fig 7a) and XRD confirmed the crystallisation of a bulk tetragonal leucite phase (Fig $6 \mathrm{c}$ ). There was also a reduction in $\mathrm{K}_{2} \mathrm{O}$ and $\mathrm{Al}_{2} \mathrm{O}_{3}$ for the residual glass compared with the original glass before heat treatments (Table 2). Calculations using Appen factors [34] indicate a reduction in network connectivity from 3.89 to 3.83 (3.80, assuming the presence of $\mathrm{Li}_{2} \mathrm{O}$ and $\mathrm{B}_{2} \mathrm{O}_{3}$ ) in the residual glass. The increased modifier content in the residual glass may have encouraged wetting of the leucite crystals, via reduction in glass network connectivity and viscosity. The estimated residual glass TEC was also raised by $0.11 \times 10^{-6} \mathrm{~K}^{-1}$ compared with the original glass formulation (assuming the presence of $\mathrm{Li}_{2} \mathrm{O}$ and $\mathrm{B}_{2} \mathrm{O}_{3}$ ), which appears to have encouraged thermal compatibility of the glass and crystal phase. The TEM images confirmed the TEC of the residual glass was matched with the crystal phase and it appeared in compression, since microcracks were only present in the leucite crystals (Figs. 2h-i and 3c). These nanoscale images also confirmed earlier work by Mackert et al. [35] regarding a critical leucite crystal size ( $<4$ microns) to avoid matrix microcracking. Incorporation of the titanate phases during the crystallisation process may also have influenced the thermal match with the glassy matrix, modifying the stress distribution or any relaxation during the cubic to tetragonal leucite transformation. The unmatched lattice parameters [36] between the two phases leading to either strain accommodation or dislocation defects. There is also the possibility of lattice parameter substitutions in $\mathrm{CaTiO}_{3}$ causing unit cell distortions 
complicating this process. The thermal and mechanical properties could therefore be influenced, but the magnitude of these effects is unknown and needs further evaluation.

The glass composition and preparation produced a high area fraction (65.5-69.3\%) of controlled leucite crystallisation when compared with earlier work $(29.3 \%)[6,7]$. The fine leucite crystals (Mean (SD) $=0.599(0.40) \mu \mathrm{m}^{2}$ ) were in close proximity to each other (Figs. 2g-i), but not exhibiting the effects of coarsening or matrix microcracking. An explanation may be formation of a "cellular membrane" (termed by Beall, [37]) around the crystallites, since the developing leucite phase was lower in silica content than the starting glass composition. This stable glass film was cited as preventing grain impingement, secondary grain growth and subsequent microcracking [37]. The leucite glass-ceramics in the current study were also highly translucent (estimated glass refractive index $(\mathrm{RI})=1.51$, Leucite $\mathrm{RI}=1.5)$ [38], making them a suitable candidate for aesthetic ceramic restorations.

In the leucite system the growth of crystallites on seeds of a chemically similar glass demonstrated the catalytic effect of seeding, using the reactive surfaces of glass particles [5]. Leucite glass-ceramics are well known as a surface nucleated system, with commercial materials (heat extruded/ machinable varieties) yielding flexural strengths of $160-165.5 \mathrm{MPa}[7,39]$. Modification to glass powder size via attritor milling prior to crystallisation was previously effective in reducing crystal size and increasing the flexural strength to 225.4-255.0 MPa [7, 8]. Longer milling times using YTZP milling media can however increase contamination $(\mathrm{Y}, \mathrm{Zr}, \mathrm{Hf})$, leading to strength reductions [7]. Reduction in industrial milling time $(\leq 45 \mathrm{~h})$ in the current formulation did not affect 
the Mean BFS, characteristic strength and the high reliability $(m=13.1$, Table 1$)$ was not significantly reduced. The experimental leucite glass-ceramics in this study also benefitted from significantly $(p<0.001)$ higher Mean BFS than commercial leucite glass-ceramics (Ceramco 3, IPS Empress Esthetic) tested previously [7, 8]. A spray drying process was added to one of the current milled glass groups to narrow the glass particle size, and with the intention of influencing the surface crystallisation. This however resulted in a significant decrease in the Weibull modulus (Table 1), indicating that further crystallisation optimisation was not achieved.

The heterogeneous growth of the leucite phase on a bulk $\mathrm{Na} / \mathrm{Ca}$ titanate phase has never been reported for the surface crystallised leucite phase and produced high Mean BFS (258-267 MPa) and reliability in this study. Importantly, Flexural strengths of Mean (SD) 109.0 (10.7) MPa were achieved when growing the leucite crystals on leucite nano-seeds [40], indicating that the growth of the current titanate transition phase in glass situ and its relationship with the glassy matrix are key to its efficient synthesis and control of the mechanical properties. This is an important step in the efficient manufacturing of this useful material that has had successful clinical outcomes (98.9\% survival at 11 years) in the anterior region [41]. Further work may reduce the dependence of these materials on powder processing to control the size and volume fraction of the crystallised phase. Controlled internal nucleation could be utilised to control or enhance the crystallisation process in leucite glass ceramics and the ease of glass-ceramic manufacture.

This paper demonstrates for the first time the synthesis of $\mathrm{Na} / \mathrm{Ca}$ titanates and their association with the efficacious nucleation and growth of a leucite glass-ceramic of 
high crystal density and flexural strength. The research significance is optimisation of the nucleation mechanism in leucite glass-ceramics provides opportunities for more efficient manufacturing and microstructural/mechanical property improvements. Improved synthesis of these high strength and reliable leucite glass-ceramics is useful for construction of aesthetic minimally invasive restorations.

\section{Acknowledgements}

The Authors gratefully acknowledge funding and support for this project from Dr Brian Schottlander (Davis Schottlander Davis Ltd.). Dr R. Bailey (School of Engineering and Materials Science, QMUL) is acknowledged for help with the SEM. A. Boebenroth (Fraunhofer IMWS) is acknowledged for TEM sample preparation. Dr Xu CaO (Cera Dynamics Ltd) for glass synthesis and supplying $\mathrm{X}$-ray fluorescence data. $\mathrm{Dr} \mathrm{H}$. Toms NMR facility manager (School of Biological and Chemical Sciences, QMUL) is kindly acknowledged. We would also like to thank Cara (the Council for At-Risk Academics) for the enormous support for one of our research team. 


\section{References}

1. Höland W, Beall GH. Glass ceramic technology. John Wiley and Sons, Inc; 2012, p. 15.

2. Shen J, Kosmač T. Advanced ceramics for dentistry. 1st ed., Elsevier Science andTechnology, Oxford; 2014, p. 23-34.

3. McMillan PW. Glass ceramics. Academic Press, New York; 1979, p. 100-102.

4. Zanotto E, Fokin V. Recent studies of internal and surface nucleation in silicate glasses. Phil Trans R Soc Lond A 2003;361:591-613.

5. Höland WH, Frank M, Rheinberger V. Surface crystallization of leucite in glass. J Non-Cryst Solids 1995;180:292-307.

6. Tošić MB, Mitrović MM, Dimitrijević RZ. Crystallization of leucite as the main phase in aluminosilicate glass with low fluorine content. J Mater Sci 2000;35:3659-67.

7. Chen X, Chadwick TC, Wilson RM, Hill R, Cattell MJ. Crystallization of high-strength fine-sized leucite glass-ceramics. J Dent Res 2010;89:1510-6.

8. Theocharopoulos A, Chen X, Wilson RM, Hill R, Cattell MJ. Crystallization of highstrength nano-scale leucite glass-ceramics. Dent Mater 2013;29:1149-57.

9. Theocharopoulos $A$, Chen X, Hill R, Cattell MJ. Reduced wear of enamel with novel fine and nano-scale leucite glass-ceramics. J Dent 2013;41:561-8.

10. Guignard M, Cormier L, Montouillout V, Menguy N, Massiot D. Structural fluctuations and role of $\mathrm{Ti}$ as nucleating agent in an aluminosilicate glass. J Non-Cryst Solids 2010;356:25-6,1368-73.

11. Beall GH, L.R. Pinckney LR. Microstructural Evolution in Some Silicate GlassCeramics: A Review. J Am Ceram Soc 2008; 91: 773-779.

12. Patzig C, Dittmer M, Höche $T$, Rüssel $C$. Temporal evolution of crystallization in MgO$\mathrm{Al}_{2} \mathrm{O}_{3}-\mathrm{SiO}_{2}-\mathrm{ZrO}_{2}$ glass ceramics. Cryst Growth Des 2012;12:2059-67.

13. Theocharopoulos A, Chen X, Karpukhina N, Hill R, Cattell MJ. Leucite glass-ceramics. US Patent 9,856,165, 2018.

14. Timoshenko SP, Woinowsky-Krieger S. Theory of plates and shells. 2nd ed. New York: McGraw-Hill; 1959, p. 70-71.

15. Dentistry - Ceramic materials. International standard ISO 6872:2008(E), 3rd ed., Switzerland, 2008,1-24.

16. Seki, V, Kennedy, GC, Am. An experimental study on the leucite-pseudoleucite problem. Am Mineral 1964; 49: 1267-1280.

17. Brian L, Phillips R, Kirkpatrick J, Putnis A. Si,Al ordering in leucite by high-resolution ${ }^{27}$ Al MAS NMR spectroscopy. Phys Chem Miner 1989;16:591-8. 
18. Kohn S, Henderson C, Dupree R. Si-Al ordering in leucite group minerals and ionexchanged analogues: An MAS NMR study. Am Mineral 1997;82:1133-40.

19. Cattell MJ, Chadwick TC, Knowles JC, Clarke RL. The crystallization of an aluminosilicate glass in the $\mathrm{K}_{2} \mathrm{O}-\mathrm{Al}_{2} \mathrm{O}_{3}-\mathrm{SiO}_{2}$ system. Dent Mater 2005;21:811-22.

20. James PF. Nucleation in glass forming systems-a review. Simmons JH, Uhlmann $\mathrm{DR}$, Beall GH editors. Advances in ceramics, nucleation and crystallisation in glasses. The American Ceramic Society, Columbus, OH; 1982. p. 14-48.

21. Farges F, Brown Jr. GE, Navrotsky A, Gan H, Rehr, JJ. Coordination chemistry of Ti (IV) in silicate glasses and melts: II. Glasses at ambient temperature and pressure. Geochim Cosmochim Acta 1996;60:3039-53.

22. Zheng $W$, Lin $M$, Cheng J. Effect of phase separation on the crystallization and properties of lithium aluminosilicate glass-ceramic. Glass Phys Chem 2013;39:142-9.

23. Cormier L, Dargaud, O, Menguy N, Henderson GS, Guignard, M, Trcera, N, Watts, B. Investigation of the role of nucleating agents in $\mathrm{MgO}-\mathrm{SiO}_{2}-\mathrm{Al}_{2} \mathrm{O}_{3}-\mathrm{SiO}_{2}-\mathrm{TiO}_{2}$ glasses and glass-ceramics: A XANES study at the Ti K- and L2,3-edges. Cryst Growth Des 2011;11:311-9.

24. Alekseeva I, Dymshits OS, Zhilin AA, Mikhailova MD, Khubetsova AA. Phase transformations in glass of the $\mathrm{MgO}-\mathrm{Al}_{2} \mathrm{O}_{3}-\mathrm{SiO}_{2}-\mathrm{TiO}_{2}$ system doped with Yttrium Oxide. Glass Phys Chem 2015;41:597-606.

25. Cattell MJ, Chadwick TC, Knowles JC, Clarke RL. The development and testing of glaze materials for application to the fit surface of dental ceramic restorations. Dent Mater 2009;25:431-41.

26. Xue X, Stebbins JF. 23Na NMR chemical shifts and local Na coordination environments in silicate crystals, melts and glasses. Phys Chem Miner 1993;20:297307.

27. Moustafa AM, Ahmed Farag IS, Salah LM. Structural characterization of substituted calcium titanate compounds $\mathrm{Ca}_{1-x} \mathrm{LaxTi}_{1-\mathrm{x}} \mathrm{Fe}_{x} \mathrm{O}_{3}$. Egypt J Solid 2004;27:213-22.

28. Becker I, Hofmann I, Müller FA. Preparation of bioactive sodium titanate ceramics. J Eur Ceram Soc 2007;27:4547-53.

29. Conforto E, Caillard D, Müller L, Müller FA. The structure of titanate nanobelts used as seeds for the nucleation of hydroxyapatite at the surface of titanium implants. Acta Biomater 2008;4:1934-43.

30. Headley T, Loehman R. Crystallization of a glass-ceramic by epitaxial growth. J Am Ceram Soc 1984;67:620-5.

31. Zanotto ED. Crystals in glass: A hidden beauty. John Wiley and Sons; 2013, p. 7-20.

32. Zhang Y, Qu C, Rao PG, Lu M, Wu JQ. Nanocrystalline seeding effect on the crystallisation of two leucite precursors. J Am Ceram Soc 2007;90:2390-8.

33. Zanotto ED, Tsuchida JE, Schneider JF, Eckert H. Thirty-year quest for structurenucleation relationships in oxide glasses. Int Mater Rev 2015;60:376-91. 
34. Bach $\mathrm{H}$, Neuroth N. Development of optical glasses. The properties of optical glass. Springer, Berlin; 1998, p. 73-81.

35. Mackert JR, Jr., Twiggs SW, Russell CM, Williams AL. Evidence of a critical leucite particle size for microcracking in dental porcelains. J Dent Res 2001;80:1574-9.

36. Ali R, Yashima M. Space group and crystal structure of the Perovskite $\mathrm{CaTiO}_{3}$ from 296 to 1720 K. J Solid State Chem 2005;178:2867-72.

37. Beall GH. Design and properties of glass-ceramics. Annu Rev Mater Sci 1992;22:109-111.

38. Deer W, Howies R, Zussman J, Wise W. Rock-forming minerals, vol. 4B. Geological Society, London; 2004, p. 304-15.

39. Höland WH, Rheinberger V, Apel E, van't Hoen C. Principles and phenomena of bioengineering with glass-ceramics for dental restoration. J Eur Ceram Soc 2007;27:1521-6.


leucite particle sizes. J Am Ceram Soc 2008;91:527-34.

41. Fradeani M, Redemagni M. An 11-year clinical evaluation of leucite-reinforced glassceramic crowns: a retrospective study. Quintessence Int 2002;33:503-10. 


\section{LIST OF TABLES}

Table 1, The results of the biaxial flexural strength testing.

Table 2, Compositional Table showing EDX results of the residual glass and leucite crystal phase (mol \%). 


\section{Tables}

Table 1

\begin{tabular}{|c|c|c|c|c|c|c|}
\hline Groups & $\begin{array}{l}\text { Mean BFS } \\
\text { MPa (SD) }\end{array}$ & $\begin{array}{c}\mathrm{m} \\
\text { value }\end{array}$ & $\begin{array}{l}\text { C.I for } \mathrm{m} \\
(95 \%)\end{array}$ & $\begin{array}{c}\sigma_{0} \\
(\mathrm{MPa})\end{array}$ & $\begin{array}{l}\text { C.I. for } \sigma_{0} \\
(95 \%)\end{array}$ & $r^{2}$ \\
\hline $\begin{array}{c}\text { Group 1 } \\
\text { Experimental } \\
\text { Leucite glass- } \\
\text { ceramic } \\
\text { (48h mill) }\end{array}$ & $262.1(31.5)^{a}$ & $9.7^{a b}$ & 7.69-12.31 & $275.4^{a}$ & $266.6-284.5$ & 0.983 \\
\hline $\begin{array}{c}\text { Group 2 } \\
\text { Experimental } \\
\text { Leucite glass- } \\
\text { ceramic } \\
\text { (71h mill) }\end{array}$ & $268.1(24.4)^{a}$ & $13.1^{\mathrm{ab}}$ & 10.51-16.33 & $278.5^{a}$ & $271.8-285.3$ & 0.94 \\
\hline $\begin{array}{c}\text { Group 3: } \\
\text { Experimental } \\
\text { Leucite glass- } \\
\text { ceramic } \\
\text { (93h mill) }\end{array}$ & $258.4(23.3)^{a}$ & $13.3^{a}$ & $10.62-16.56$ & $268.1^{a}$ & $262-274.8$ & 0.973 \\
\hline $\begin{array}{c}\text { Group 4: } \\
\text { Experimental } \\
\text { Leucite glass- } \\
\text { ceramic } \\
\text { (93h mill, SPD) }\end{array}$ & $255.9(35)^{a}$ & $8.3^{b}$ & $6.5-10.55$ & $270.9^{a}$ & $260.8-281.5$ & 0.987 \\
\hline
\end{tabular}

* Significant differences indicated by different superscript letters, $m=$ Weibull modulus; $\sigma_{0}=$ Characteristic strength, C.I. = confidence intervals. SPD = spray dried powder. 
Table 2

\begin{tabular}{|l|c|c|c|c|c|c|c|c|}
\hline $\begin{array}{l}\text { Elements } \\
(\mathrm{mol} \%)\end{array}$ & $\mathrm{SiO}_{2}$ & $\mathrm{Al}_{2} \mathrm{O}_{3}$ & $\mathrm{~K}_{2} \mathrm{O}$ & $\mathrm{CaO}$ & $\mathrm{TiO}_{2}$ & $\mathrm{Na}_{2} \mathrm{O}$ & $\mathrm{Li}_{2} \mathrm{O}$ & $\mathrm{B}_{2} \mathrm{O}_{3}$ \\
\hline $\begin{array}{l}\text { Residual } \\
\text { glass }\end{array}$ & 69.0 & 8.0 & 9.1 & 4.8 & 4.0 & 4.9 & - & - \\
\hline $\begin{array}{l}\text { Leucite } \\
\text { Crystal }\end{array}$ & 59.0 & 21.5 & 19.1 & 0.2 & - & 0.2 & - & - \\
\hline
\end{tabular}

Compositions expressed in mol $\%, \mathrm{Li}_{2} \mathrm{O}$ and $\mathrm{B}_{2} \mathrm{O}_{3}$ were not analysed. 


\section{LIST OF FIGURES}

Figure 1, DSC plot showing the results of the nucleation experiment.

Figure 2, TEM photomicrographs of; glass frit sample $(A, B)$; glass frit after nucleation step $\left(592^{\circ} \mathrm{C}, 1 \mathrm{~h}\right)$ showing phase domains (C); glass frit after nucleation step $\left(602^{\circ} \mathrm{C}, 1 \mathrm{~h}\right)$ showing crystallites in the bright field contrast mode (D); dark field mode (E); and associated phase domains (F); glass powder after $592^{\circ} \mathrm{C}, 1 \mathrm{~h} / 1040^{\circ} \mathrm{C}, 0.5 \mathrm{~h}$ heat treatment with extensive crystal twinning, lack of matrix microcracking $(\mathrm{G}, \mathrm{H})$ and crystal inclusions (I).

Figure 3, TEM micrographs of glass powder after $592^{\circ} \mathrm{C}, 1 \mathrm{~h} / 1040,0.5 \mathrm{~h}$ heat treatment showing crystal twinning $(A)$; and unit cell d spacing $(B)$; glass powder after $602^{\circ} \mathrm{C}, 1 \mathrm{~h} / 1040,0.5 \mathrm{~h}$ heat treatment showing leucite crystal twins (C, D) and unit cell d spacing (E); SEM photomicrograph of $592^{\circ} \mathrm{C}, 1 \mathrm{~h} / 1040^{\circ} \mathrm{C}, 0.5 \mathrm{~h}$ heat treated powder, showing uniform distribution of fine leucite crystals in the glassy matrix, and crystal/matrix inclusions (F).

Figure 4, EDX spectra of the residual glass and leucite crystal phase, with inset picture showing specific areas analysed $\left(592^{\circ} \mathrm{C}, 1 \mathrm{~h} / 1040,0.5 \mathrm{~h}\right.$ heat treatment).

Figure 5, STEM-HAADF Images showing the elemental distribution via EDX in; the glass-ceramic frit $\left(592^{\circ} \mathrm{C}, 1 \mathrm{~h} / 1040,0.5 \mathrm{~h}\right.$ heat treatment) (a); and domains within the crystallites (b). Domains within the crystallite for $602^{\circ} \mathrm{C}, 1 \mathrm{~h} / 1040$, $0.5 \mathrm{~h}$ heat treated glass-ceramic (c).

Figure 6, XRD plots indicating (a); the spray dried glass powder following the nucleation step $\left(602^{\circ} \mathrm{C}, 1 \mathrm{~h}\right)$; the amorphous glass frit following the nucleation step $\left(602^{\circ} \mathrm{C}, 1 \mathrm{~h}\right)(\mathrm{b})$; after the $592^{\circ} \mathrm{C}, 1 \mathrm{~h} / 1040,0.5 \mathrm{~h}$ powder heat treatment showing a tetragonal leucite phase (c). $\mathbf{\Delta}=$ peaks for tetragonal leucite phase.

Figure 7a, ${ }^{27} \mathrm{Al}$ MAS-NMR spectra of the glass-ceramic powder (a), powder heat treated at $602^{\circ} \mathrm{C}$ (b) and $592^{\circ} \mathrm{C}$ (c) for 1 hour and untreated glass powder (d).

Figure $7 \mathbf{b},{ }^{23} \mathrm{Na}$ MAS-NMR spectra of the glass-ceramic powder (a), powder heat treated at $602^{\circ} \mathrm{C}$ (b) and $592^{\circ} \mathrm{C}$ (c) for 1 hour and untreated glass powder (d). 
Figure 1.




Figures 2 a-i

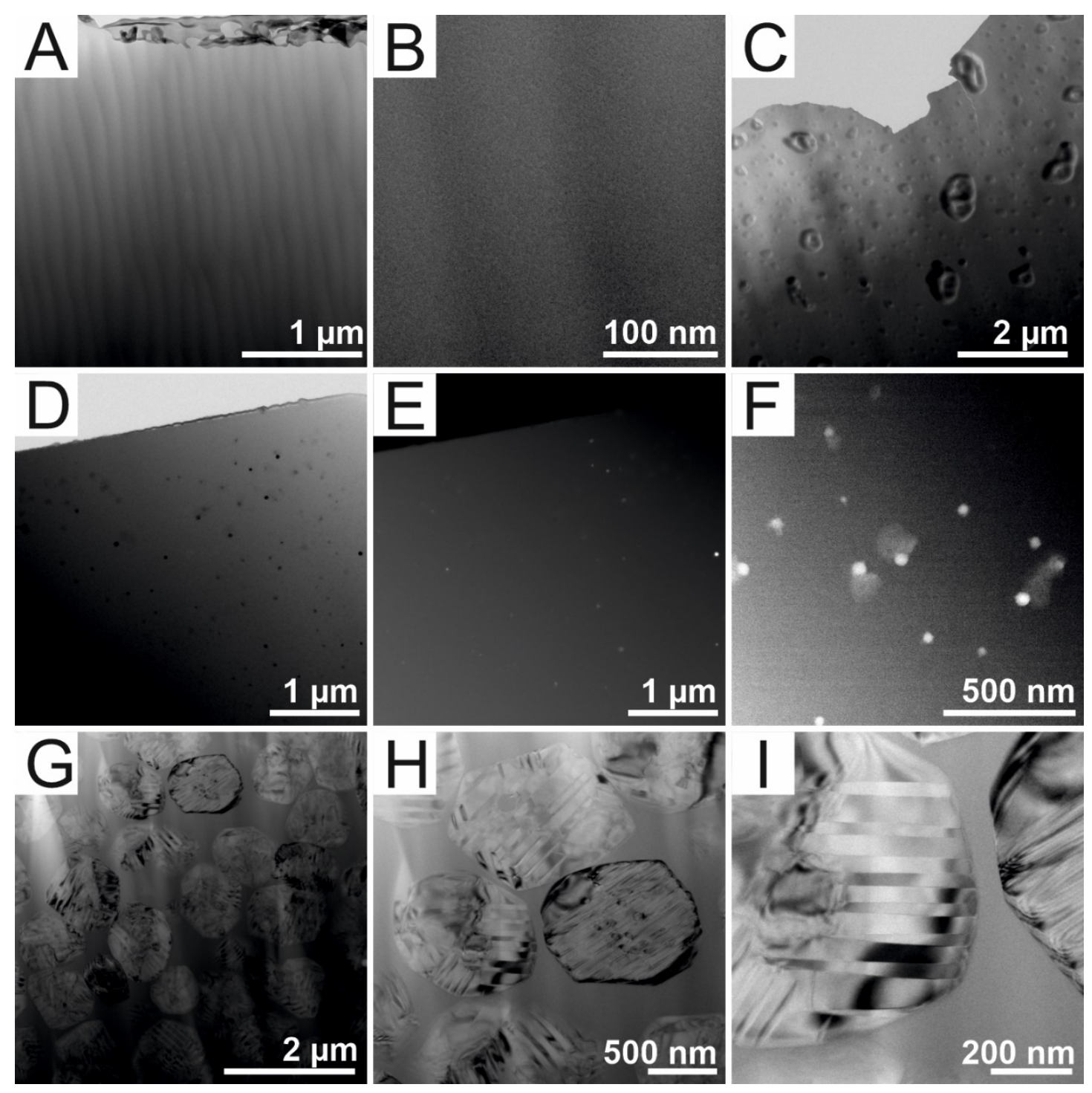


Figures 3a-f
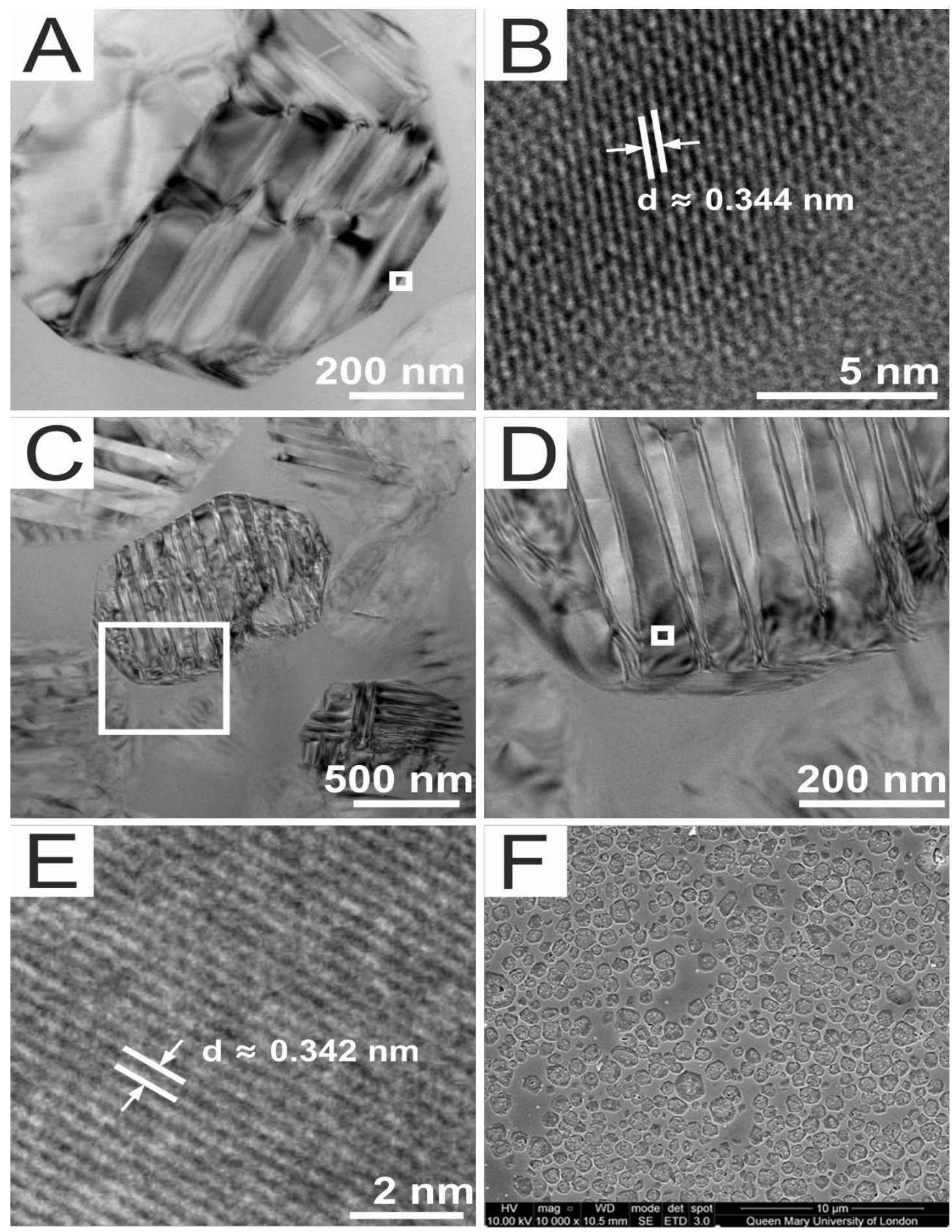
Figure 4.
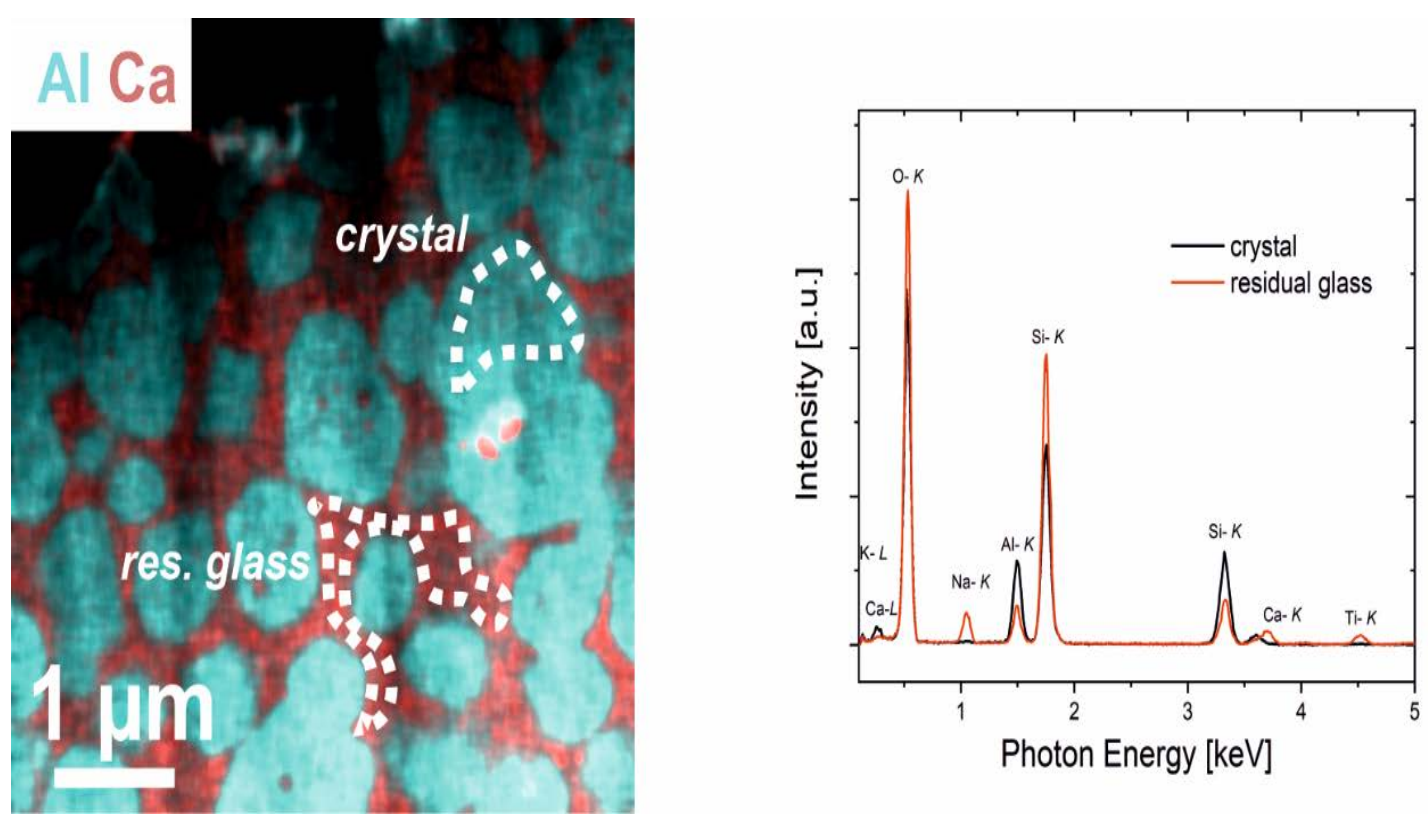
Figure 5a
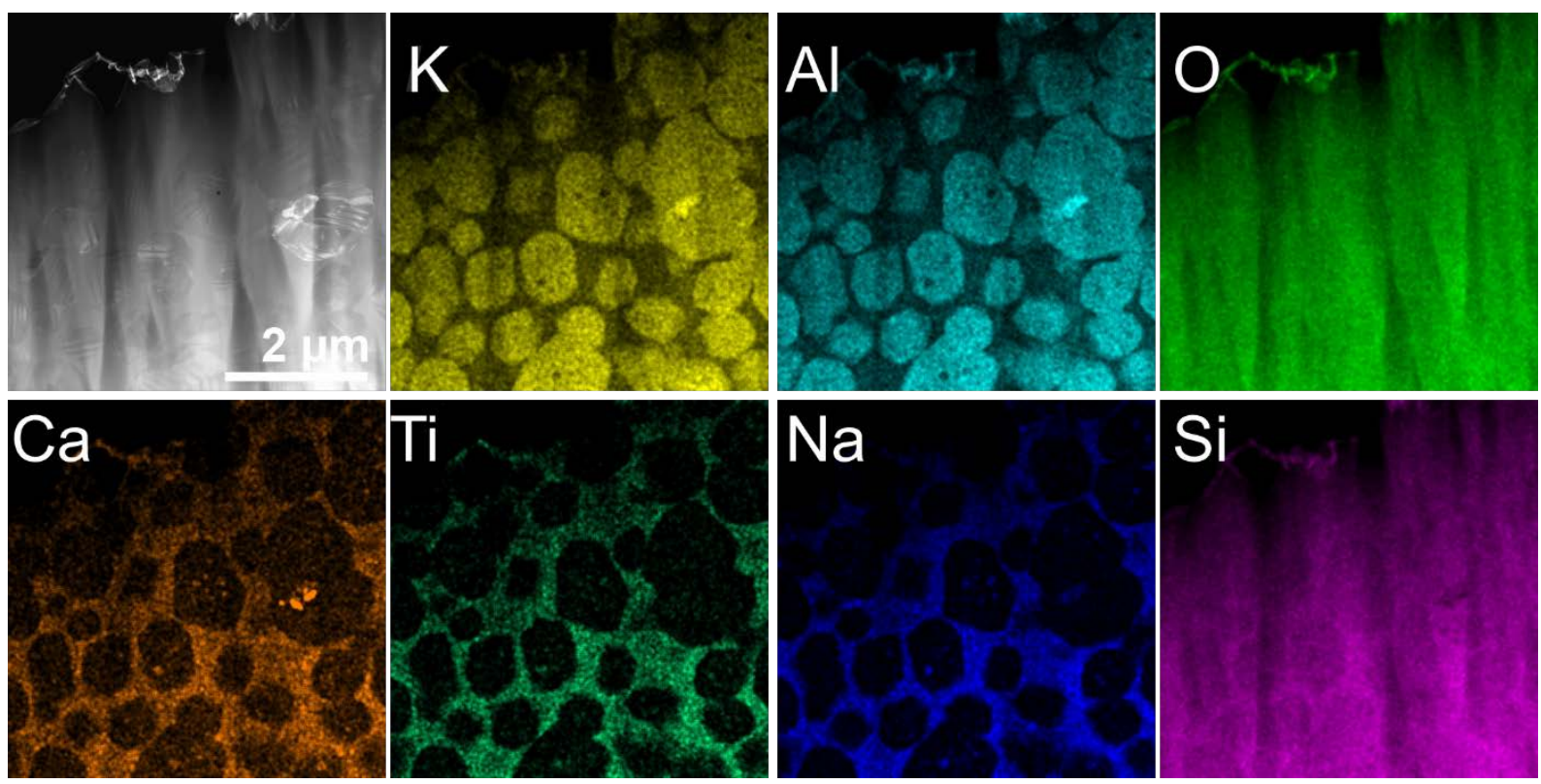

Figures 5b, c (bottom row images)
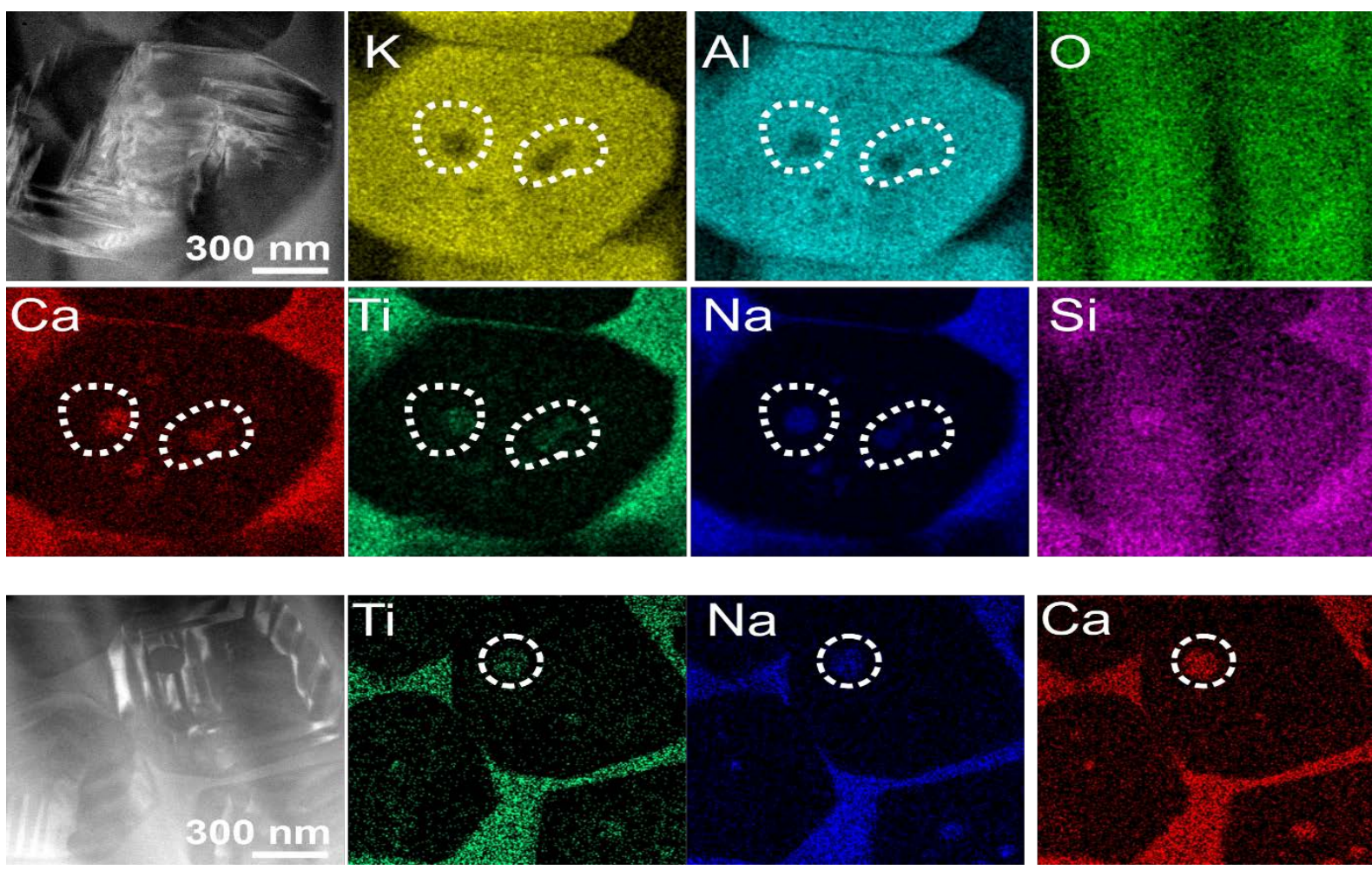
Figure 6.

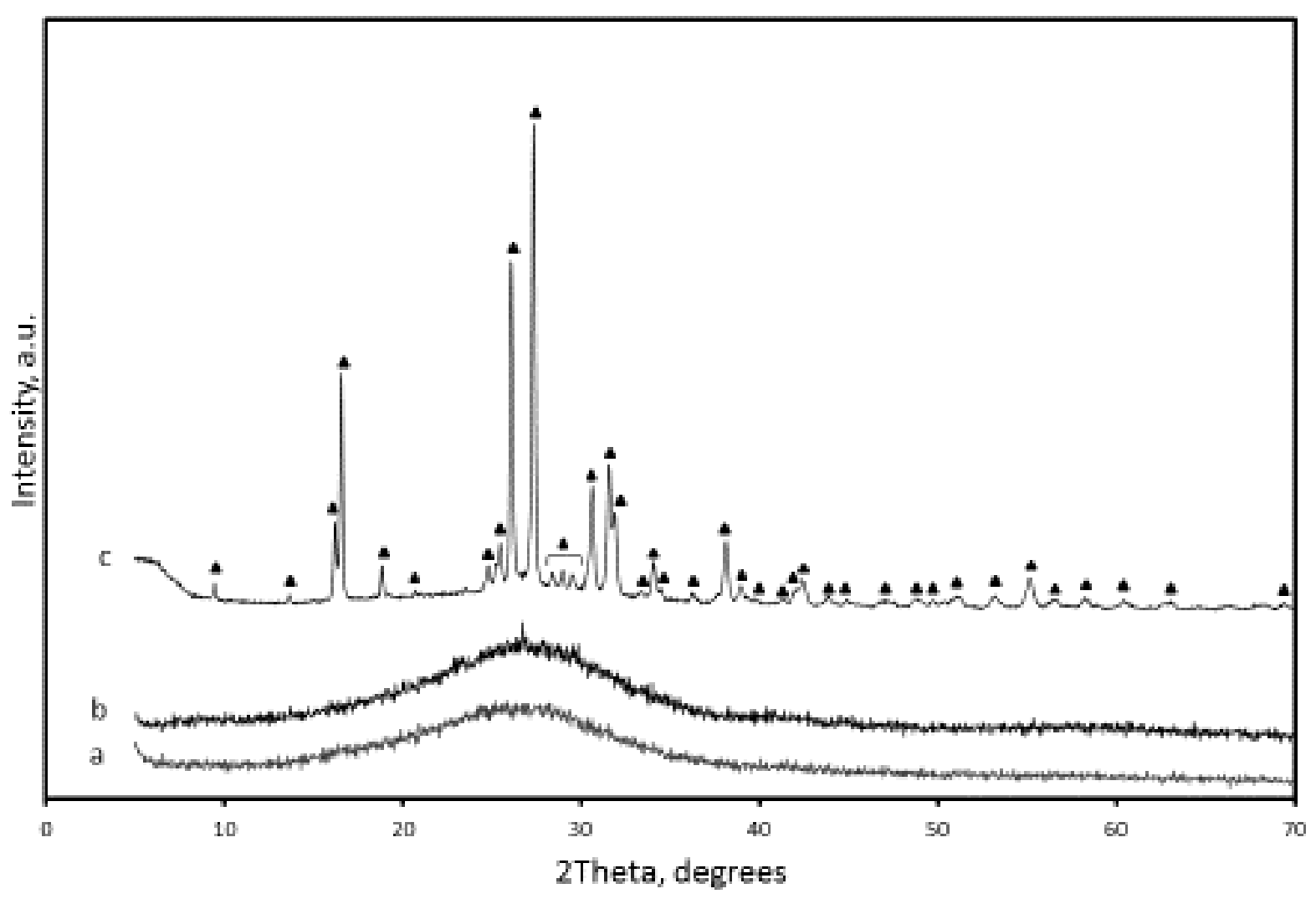


Figure 7a

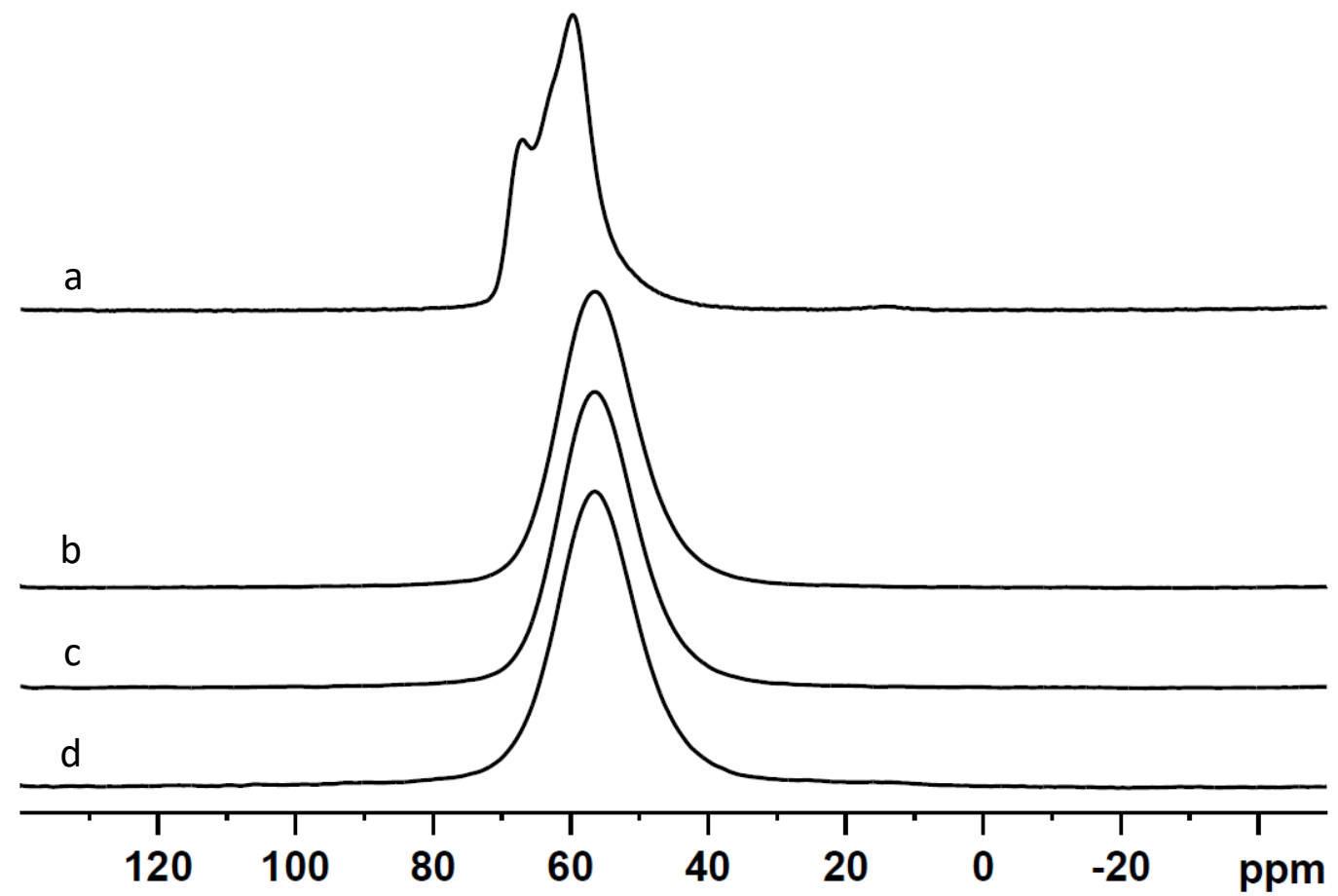

Figure $7 b$

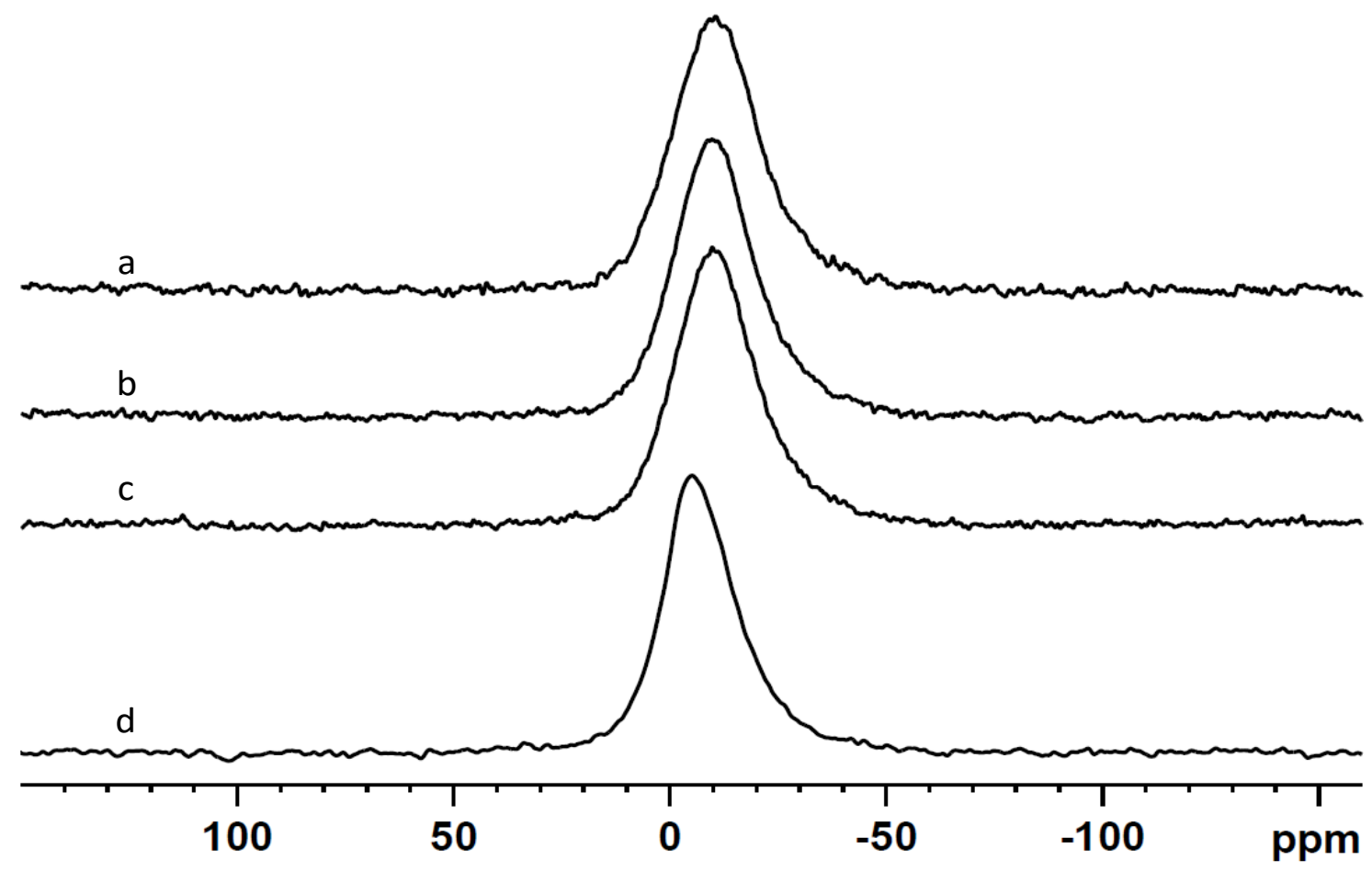

